\title{
Assessment of Pollution Potential of Cyanide-Bearing Tailings Dam*
}

\author{
E. K. Asiam and D. Kugblenu
}

Asiam, E. K. and Kugblenu, D. (2010), “Assessment of Pollution Potential of Cyanide-Bearing Tailings Dam”, Ghana Mining Journal, Vol. 12, pp. 38 - 42.

\begin{abstract}
This study ascertained the types of chemical species that are formed in tailings material of gold leaching plants and assessed their short and long term pollution potential capabilities. The results revealed that chemical, biochemical and geochemical reactions were occurring in the tailings material; producing complexed cyanides, bicarbonates and nitrates which accumulate with depth in the tailings material while ammonium, carbonate and sulphate ions decreased with depth. Heavy metal accumulation particularly $\mathrm{Mn}, \mathrm{Pb}, \mathrm{Zn} \mathrm{Cu}, \mathrm{Fe}$ were also observed to increase with depth. It was concluded that the cyanide bearing tailings material has short term pollution potential of free cyanides, ammonium ions, sulphates ions and a long term risk of, complexed cyanide, nitrate and increase in water hardness due to bicarbonate ion. Heavy metal pollution and a decrease in $\mathrm{pH}$ are also possible.
\end{abstract}

\section{Introduction}

Gold normally occurs in association with some amount of waste materials (gangue) and after beneficiation of the ore the gangue which becomes the solid phase of the tailings is deposited in impoundment structures (tailings dam) to maximize space in the beneficiation plant. Therefore, tailings dams are unavoidable structures of any mining operations. During the extraction of gold from quartzite and sulphide ores, cyanide is used as a lixiviant and as a result the tailings will always contain some amount of cyanide.

Cyanide can impact adversely on the environment in three distinct ways namely: producing direct and on-going poisoning through volatilization of hydrogen cyanide gas, interfering with certain metabolic pathways as a result of formation of certain metal thiocyanate complexes and producing toxic levels or deficiencies of certain metal ions in natural water by complexing with them (Clark and Linkson, 1997). Furthermore, if the solid phase of the tailings is not stable (if sulphides are present) then there exists the potential of acid mine drainage, a phenomenon that tends to lower the $\mathrm{pH}$, leach and mobilize heavy metals into the geoenvironment (Marcus, 1997).

Consequently, seepage from such tailings material is generally not of a suitable quality for direct discharge into the environment during and after deposition; as it has the potential to impact adversely on the ecosystem. As such, some attempts are normally made nowadays to detoxify the tailings' liquid and also line the dam's surface with imper- vious materials to contain any liquid and thereby prevent contamination of the geo-environment. Unfortunately, the liner materials that are used have limited life span and lining is not a suitable option for in-pit tailings impoundment structures because of their irregular configuration (Lane, 2000). In addition, there seems to be lack of adequate data on in-situ transformation of chemical species within the tailings material itself.

As a result of these limitations, liquid contained in tailings is a source of substantial concerns to regulatory agencies since several unplanned releases from tailings dam have occurred around the world such as Los Frailes in Spain in 1998, Aurul in Romaniain 2000 and Merriespruit, in South Africa in 1994 among others which have caused extensive destruction to life and property in some cases (Anon, 2002; Trancoso, 1990). Hence, potential chemical impact and contaminant transport from cyanide bearing-tailings material cannot be over emphasised since detoxification and other methods like lining do not ensure total environmental protection.

As gold mining operations nowadays have concentrated on exploiting low grade surface deposits in many countries, large tailings dams are inevitable to store the ensuing tailings.

Hence, there is the need to generate more data on in-situ reactions occurring in tailings material in order to design, operate and decommission tailings facility in a manner that will not only be economical but will also ensure public safety, environmental protection and industry trust.

\footnotetext{
* Manuscript received March 08, 2009

Revised version accepted November 11, 2009
} 
This paper therefore attempts to identify the types of chemical species that are formed in tailings dam in a tropical environment and to assess their pollution potential.

\section{Location and Climate}

The tailings dam on which this study was carried out is about 100 ha and is located in one of the gold mines in Ghana. A tailings material was deposited in this dam for 6 years and thereafter rehabilitated with plant cover. The area is classified as having a humid tropical climate characterized by hot and wet rainy periods and mild temperatures. The mean air temperature is about $26{ }^{\circ} \mathrm{C}$ and the mean monthly relative humidity increases from $65 \%$ in January to a maximum of over $80 \%$ in August and September. The mean annual rainfall is about $1800 \mathrm{~mm}$.

\section{Methodology}

The following were carried out:

\subsection{Sample Collection}

A mechanically powered auger was used to drill four holes: one located at eastern, western, northern and southern sections of the tailing dam. Each hole was $100 \mathrm{~m}$ from the embankment. Samples were taken at various depths as drilling progressed until water was encountered when the drilling was stopped.

\subsection{Laboratory Investigations}

The moisture content of the samples was determined by drying $5 \mathrm{~g}$ each at $105^{\circ} \mathrm{C}$ for 12 hours, cooled in desiccator and then weighed.

A composite sample was prepared from the samples from the four holes and particle size determination was carried out using sieve analysis. Another composite sample for each hole was also prepared for X-ray diffractometry (Siemens D500) analysis, ore microscopy examination (Leitz SmLux- Pol) and for identification of Nitrosomona and Nitrobacter bacteria using Vinogradsky (1952) method.

About $1 \mathrm{~g}$ of the composite sample of the four holes was digested with aqua regia for one hour and then filtered into a-100 $\mathrm{ml}$ flask. The filter cake was washed with distilled water and made to the mark. The filtrate was analyzed for some elements.

About $200 \mathrm{~g}$ (wet) of each sample from each hole were pulped to $50 \%$ solid (taking into account the moisture content of the sample) with distilled water and leached for 24 hours. The pulp was filtered into a-250 $\mathrm{ml}$ flask and made to the mark. The following were carried on the sample of the filtrate: Measurement of some physico-chemical properties, elemental analysis using AAS (Philips
480D) and determination of some anions by ion chromatograph (Dx 2000 isp) were carried out on the sample and filtrate.

\section{Results and Discussions}

During the drilling of the holes water was encountered at depth of $6.5 \mathrm{~m}, 4.5 \mathrm{~m}, 3.3 \mathrm{~m}$ and $2.5 \mathrm{~m}$ for the northern, eastern, southern and western holes respectively. The results obtained for northern hole were similar to the other holes. Therefore, the results for the northern hole were used in the detailed discussions because of its greater depth compared to the rest of the holes.

The results of the particle size analysis showed that $40 \%$ of the particles are sand, $55 \%$ silt and $5 \%$ clay indicating the tailings material can be classified as silty-sand. Thus, it can be inferred that the tailings material will be permeable to liquid and gases and desiccation of the material will be possible. As a result, the moisture content of the samples was found to increase with depth increasing from $12 \%$ to $19 \%$ within a- $6 \mathrm{~m}$ depth.

The X-ray diffractometry analysis revealed that the main mineral was quartz while the minor minerals were pyrite, muscovite and kaolinite. The microscopic examinations further showed that many of the pyrite grains have been altered or corroded. Thus, it can be inferred that the pyrites were being weathered or undergoing geochemical reaction.

Consequently, a relatively high amount of sulphate ions was found in the tailings mass. It can be seen in Fig. 1 that the sulphate ion concentration decreased with depth. The decrease could be due to its conversion to gypsum $\left(\mathrm{CaSO}_{4} \cdot 2 \mathrm{H}_{2} \mathrm{O}\right)$ by $\mathrm{Ca}^{2+}$ ion (see Equation 1) whose concentration was high in the tailings (see Fig. 2). No gypsum was detected in the X-ray diffractometry analysis as it may be in amorphous state. Sulphate can cause water hardness and also impact taste of water.

$\mathrm{Ca}^{+}+\mathrm{SO}^{2+}+2 \mathrm{H}_{2} \mathrm{O}=\mathrm{CaSO}_{4} \cdot 2 \mathrm{H}_{2} \mathrm{O}$

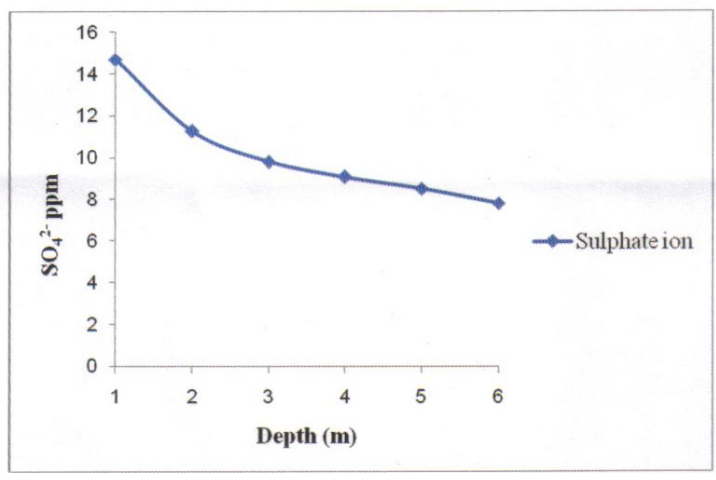

Fig. 1 Variation of Sulphate Ion Concentration with Depth 


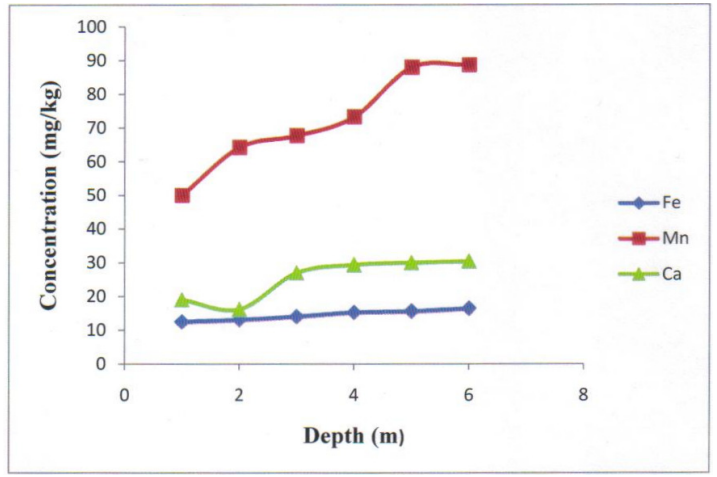

Fig. 2 Variation in Fe, Mn and Ca Concentra tion in the Tailings Material with Depth

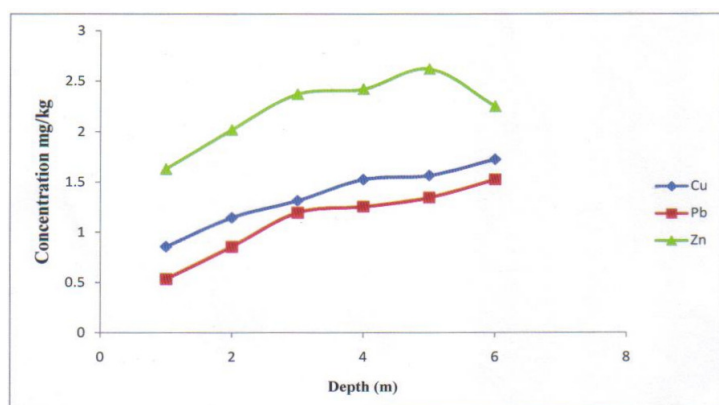

Fig. 3 Variation in $\mathrm{Cu}, \mathrm{Pb}$ and $\mathrm{Zn}$ Concentration in the Tailings Material with Depth

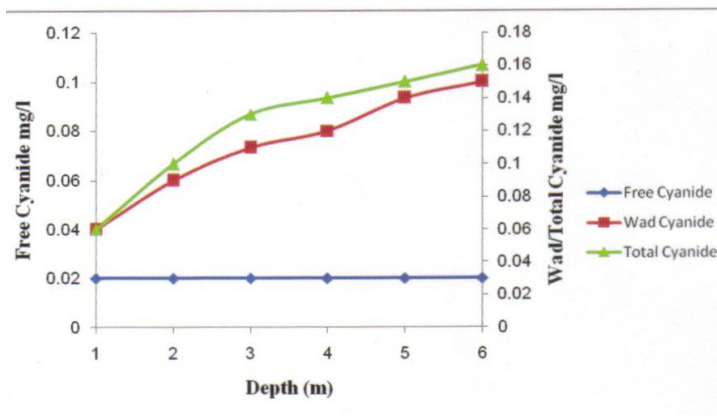

Fig. 4 Variation in free Cyanide, WAD Cyanide and Total Cyanide Levels with Depth

The results of the AAS elemental (total) analysis are given in Table 1, while the water soluble elements are plotted in Fig. 2 and 3. It can be seen that the elements in the solid phase are also present in the interstitial liquid phase of the tailings material. Hence, the elements in the water soluble phase might have been derived from the solid phase of the tailings material. Furthermore, the concentration of the water soluble elements increased with depth. Notably, there is almost 50\% increase in Manganese concentration at depth of 5 $\mathrm{m}$, iron was $30 \%$ and lead $200 \%$. This accumulation could be due to weathering activity in the tail-

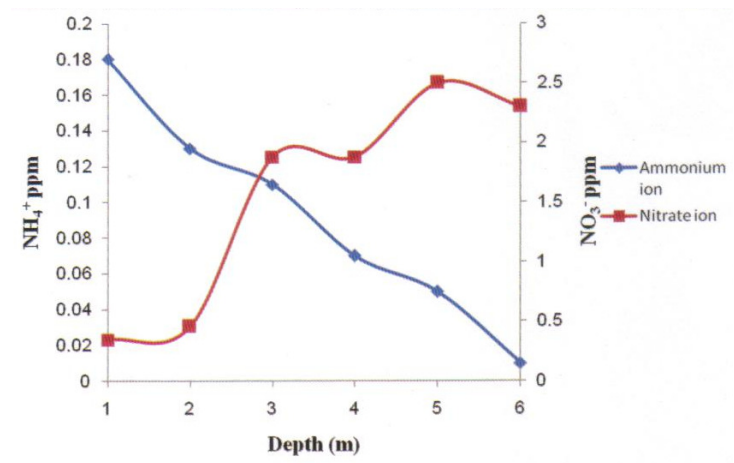

Fig. 5 Variation in Ammonium and Nitrate Concentrations with Depth

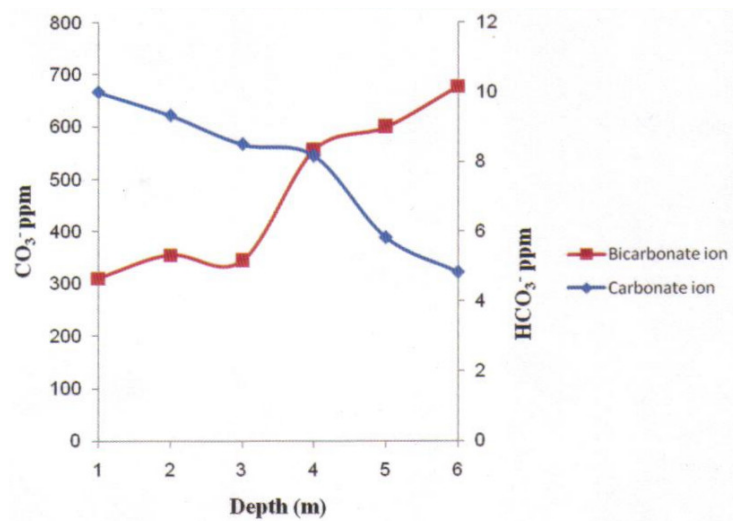

Fig. 6 Variation in Carbonate and Bicarbonate Ions Concentration with Depth

Table 1 Analysis of elements in the Solid Phase of the Composite Sample of the 4 Holes

\begin{tabular}{|c|l|l|l|l|l|l|}
\hline Element & $\mathrm{Fe}$ & $\mathrm{Mn}$ & $\mathrm{Zn}$ & $\mathrm{Cu}$ & $\mathrm{Pb}$ & $\mathrm{Ca}$ \\
\hline $\begin{array}{c}\text { Concentration } \\
\text { (ppm) }\end{array}$ & 17806.6 & 54.3 & 10.4 & 16.3 & 6.8 & 28.7 \\
\hline
\end{tabular}

ings material. The relatively high level of $\mathrm{Zn}, \mathrm{Cu}$ and $\mathrm{Fe}$ in the liquid and solid phase of tailings material may give rise to more cyanide effectively being retained in the tailings material through complex ion formation thereby stabilising cyanide that would otherwise have been available for hydrolysis, volatilization and eventual venting to the atmosphere.

Consequently, the total cyanide and the weak acid dissociable (WAD) cyanide levels were found to increase with depth, while free cyanide concentration was almost constant at all depth (see Fig. 4). Thus, it can be inferred that most of the cyanides were either strongly or weakly complexed. The complexed cyanide species are not toxic but may break down in the long term, producing free cyanide which is toxic (Smith and Mudder, 1991). 
The analysis of $\mathrm{NH}_{4}^{+}$and $\mathrm{NO}_{3}{ }^{-}$is presented in Fig. 5. It can be observed that ammonium concentration decreased while that of nitrate ion increased with depth. The results of microbial identification confirmed the presence of Nitrosomona and Nitrobacter bacteria in the tailings material. This information suggests that bio-chemical reactions are occurring in the tailings namely: $\mathrm{NH}_{4}{ }^{+}$is converted to $\mathrm{NO}_{2}^{-}$by Nitrosomona bacteria, while the $\mathrm{NO}_{2}^{-}$ was further converted to $\mathrm{NO}_{3}^{-}$by Nitrobacter. Nitrate can produce methemoglobinemia in babies (Chanlett, 1977). Ammonium ion can impact oduor to water.

The level of $\mathrm{CO}_{3}{ }^{-}$and $\mathrm{HCO}_{3}{ }^{-}$in the tailings is presented in Fig. 6. It can be seen that while $\mathrm{CO}_{3}{ }^{-}$ level decreased with depth in contrast, the $\mathrm{HCO}_{3}{ }^{-}$ level is increased with depth. The $\mathrm{pH}$ of the tailings slurry during the time of deposition was greater than 10 and lime was used to control the $\mathrm{pH}$. The carbon dioxide of the atmosphere can react with the excess lime as follows:

$\mathrm{Ca}(\mathrm{OH})_{2}+\mathrm{CO}_{2}=\mathrm{CaCO}_{3}+\mathrm{H}_{2} \mathrm{O}$

The carbonate can also be converted to bicarbonate through a reaction like;

$\mathrm{CaCO}_{3}+\mathrm{CO}_{2}+\mathrm{H}_{2} \mathrm{O}=\mathrm{Ca}^{2+}+2 \mathrm{HCO}_{3}^{-}$

It is also likely that part of the bicarbonate may come as by-product of cyanide attenuation at $\mathrm{pH} \geq$ 10.

$\mathrm{CN}^{-}+2 \mathrm{H}_{2} \mathrm{O}=\mathrm{NH}_{3}+\mathrm{HCO}_{3}^{-}$

Furthermore, at $\mathrm{pH}$ between 6.0 and 6.5 carbonate can be converted to bicarbonate as follows:

$\mathrm{CO}_{3}^{2-}+\mathrm{H}^{+}=\mathrm{HCO}_{3}^{-}$

The $\mathrm{pH}$ of the tailings material is within this range (Table 2). These reactions may explain the formation of more bicarbonate with depth.

Table 2 Physico-chemical Analysis at 1:1 Solid/Liquid Ratio
The foregoing discussions established that geochemical, biochemical and chemical reactions were occurring in the tailings material producing new chemical species. As a result, the physicochemical analysis (Table 2) showed that the conductivity and TDS in the tailings pore water increased with depth while the $\mathrm{pH}$ of the tailings material decreased with depth.

\section{Conclusions}

The study confirmed that the tailings material is a silty-sand and therefore liquid can be mobilized through it. It was also established that chemical, biochemical and geochemical processes were occurring in the tailings material producing chemical species that tend to accumulate with depth. These phenomena have brought about increase in conductivity and total dissolved solid values.

The relatively high level of water soluble $\mathrm{Zn}, \mathrm{Cu}$ and $\mathrm{Fe}$ in liquid and solid (as it weathers) phases of the tailings material may retain cyanide through complex ion formation and thereby delay its attenuation through hydrolysis, volatilization and microbial activity.

The short term pollution potential was identified as free cyanide, ammonium ion, sulphates and carbonates while the long term risks will be complexed cyanides, nitrates, increase in bicarbonates (water hardness) and accumulation of heavy metals like lead, manganese, zinc and lowering of $\mathrm{pH}$. The decommissioning of such tailings material has to deal with these issues.

\section{References}

Anon. (2002), "Review of Tailings Dam Incident Data", Mining Environment Management, Vol. 9. pp. 7-8.

Chanlett, E. T. (1979), Water Resources and Environmental Protection, McGraw-Hill Publishers Inc. New York, 585 pp.

Clarke, M. C. and Linkson, P. B. (1997), "Path Way of Cyanide in Tailings", In: Proceedings of Mining and Environment, A Professional Approach, National Conference-Brisbane, Australia, pp. $84-87$.

Knowles, C. (1976), "Microorganism and Cyanide", Microbiological Reviews, Vol. 40, No.3, pp. 652- 680 .

Lane, J. C. (2000), "In-pit Tailings Disposal Marymia Gold Operation: Case History", Soil and Rock Engineering PTY Ltd, pp. 1-24.

Marcus, J. J. (1997), "Mining and Environmental Hand Book: Effects of Mining on the Environment and American Environmental Controls on Mining", Imperial College Press, London, pp. $599-609$. 
Troncoso, J. (1990), "Failure Risks of Abandoned Tailing Dams", In: Proceedings Int. Symposium on Safety and Rehabilitation of Tailings Dam, Australian National Committee on large Dams/ICOLD, 850 pp.

Smith, A. and Mudder, T. (1991), Chemistry and Treatment of Cyanidation Wastes, Mining Journal Books Ltd, London, 345 pp.

Vinogradsky, V. I. (1952), The microbiology of Soils, Academy of Science, USSR, Moscow, $245 \mathrm{pp}$.

\section{Authors}

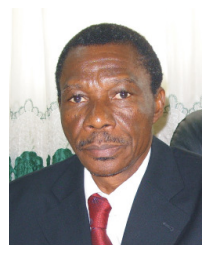

E. K. Asiam is an Associate Professor of Mineral Engineering. He holds a BSc and $\mathrm{PhD}$ degrees from the Kwame Nkrumah $\mathrm{h}$ University of science and Technology (KNUST), Kumasi. He lectures in Heap Leaching Technology, Alluvial mining, Hydrometallurgical Applications, Metallurgical Plant design and Operations, and Environmental Management and Safety. He has researched and consulted extensively on processing of refractory gold ores and environmental quality assessment and management.

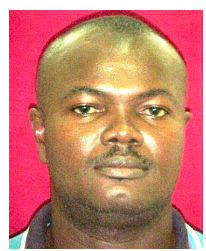

D. Kugblenu holds BSc and MSc degrees from the Kwame Nkrumah University of Science and Technology, Kumasi. He has worked with the Environmental Section of Goldfields Ghana Limited, Tarkwa Mine. 